\title{
A BELEZA E SENSUALIDADE QUE EMANA DO SADISMO E CRUELDADE: O CONTO $A$ TATUAGEM DE TANIZAKI JUN'ICHIRÔ
}

\author{
Waldemiro Francisco Sorte Junior ${ }^{l}$
}

Resumo: O presente artigo examina a construção da beleza e sensualidade a partir de uma estética marcada pelo sadismo, perversão e crueldade nas obras de Tanizaki Jun'ichirô, por intermédio da análise do conto A Tatuagem (Shisei), publicado em 1910. Os trechos apresentados da obra demonstram que elementos usualmente ligados a sentimentos negativos, como o sadismo e a crueldade, encontram-se no conto intrinsecamente conectados a valores estéticos clássicos, de tal sorte que o despertar da sensualidade e beleza suprema na heroína é um resultado direto de desejos secretos e latentes de sadismo, crueldade e perversão, instigados pelo tatuador protagonista.

Palavras-chave: Tanizaki Jun'ichirô, período Edo, beleza, sensualidade, sadismo.

Abstract: This article examines the construction of beauty and sensuality through an aesthetic approach which emphasizes cruelty, sadism and perversion, in the works of Tanizaki Jun'ichirô. Such an analysis is centered on the presentation and detailed discussion of several passages of the tale entitled The Tattoo, first published in 1910. The passages show that elements usually connected to dreadful feelings, such as sadism and cruelty, are intrinsically related to classical aesthetic values in the tale. In fact, the ultimate state of sensuality and beauty reached by the heroin by the end of The Tattoo is a direct result of secret and dormant desires of sadism, cruelty and perversion, which emerge through the intervention of the tattooer.

Keywords: Tanizaki Jun'ichirô, Edo Period, beauty, sensuality, sadism.

\section{Introdução}

Este artigo se propõe a discutir a associação da sensualidade e beleza com o sadismo, crueldade, tenebrosidade e perversidade na literatura de Tanizaki Jun'ichirô,

1 Doutor em Desenvolvimento Internacional pela Universidade de Nagoya, Licenciado em Letras Japonês pela Universidade de Brasília, Bacharel em Direito pelo Centro Universitário de Brasília, Bacharel em Administração de Empresas pela Universidade de Brasília. E-mails para contato: wald russo@yahoo.com; waldemiro.junior@planejamento.gov.br. 
por intermédio da análise do conto A Tatuagem (Shisei 刺青), publicado em 1910. O presente estudo demonstra, por meio da apresentação e discussão de trechos do referido conto, a forma pela qual o autor utiliza elementos usualmente ligados a sentimentos negativos, especialmente o sadismo e a crueldade, como componentes na busca pelo belo e na construção da sensualidade. Na verdade, observa-se no conto A Tatuagem (doravante denominada Shisei), que elementos soturnos e sombrios unem-se a atributos considerados positivos e castos pela ótica da estética clássica, criando uma ambientação na qual a perversidade e tenebrosidade tornam-se partes intrínsecas da beleza e sensualidade.

O tema em apreço possui relevância para a teoria literária por tratar de uma questão de caráter estético que, apesar de antiga, ainda desperta polêmicas. Connelly (2003) assevera que, a partir do século XIX, o grotesco deixa de possuir papel meramente periférico na arte e com o Romantismo passa a ser encarado como forma alternativa de expressão estética, em contraste aos padrões clássicos de beleza. Não obstante, observase que ainda nos tempos atuais é polêmica a utilização de elementos grotescos, cruéis e sádicos para exprimir valores estéticos relacionados à beleza e sensualidade. As obras do cineasta Kim Ki-Duk, por exemplo, muitas vezes parecem tentar demonstrar que a beleza pode ser fruto da crueldade e violência. O próprio cineasta chega a afirmar que a violência em si é bela (DECCAN CHRONICLE, 2013). Dessa forma, possui importância literária o esforço de examinar a construção do belo a partir da estética do perverso ou grotesco. O presente estudo mostra-se, portanto, significativo, na medida em que demonstra como Tanizaki cria a beleza e sensualidade a partir de temas sombrios.

O presente artigo encontra-se dividido em quatro seções, incluindo esta introdução. Na seção a seguir, será feita uma breve apresentação da carreira literária de Tanizaki Jun'ichirô, com ênfase nas principais características de cada uma de suas fases. A terceira seção será dedicada a uma análise e discussão da obra Shisei, identificando trechos do conto que corroboram o tema objeto deste artigo. A seção quatro conclui o presente estudo.

\section{A carreira literária de Tanizaki Jun'ichirô}

Tanizaki Jun'ichirô (1886-1965) teve uma extensa carreira literária de mais de cinquenta anos, que se inicia com a publicação de Shisei em 1910 e se prolonga até a conclusão em 1961 do seu último livro, Diário de um velho louco (Fûten rôjin nikki 瘋廎 老人日記) (DODD, 2012: 151). Para fins didáticos, é comum dividir a sua vida literária em três estágios principais: (i) o primeiro estágio inicia-se com a publicação de Shisei em 1910; (ii) o segundo inicia-se com a publicação de Alguns Preferem Urtigas (Tade kuu mushi 蓼喰ふ虫) em 1928; e (ii) o terceiro inicia-se em 1956 com a publicação de A Chave (Kagi 鍵) (LIPPIT, 1977: 224-225).

A primeira fase da vida literária de Tanizaki é marcada por temas relacionados ao sadismo e à sensualidade o que, segundo Seidensticker (1966: 251), parece ser um 
resultado de forte influência de autores ocidentais. Na segunda fase de sua carreira, Tanizaki tende a se afastar de tais temas, assim como de tendências relacionadas ao movimento antinaturalista (hanshizen shugi 反自然主義), entregando-se mais à subjetividade. A terceira fase de sua carreira é marcada pelo retorno as suas raízes japonesas e valorização da tradição e de padrões estéticos do Japão (GOLLEY, 1995: 365-366; TSURUTA, 2000: 239-240). Hibbett (1966: 930) afirma que Tanizaki foi um dos únicos escritores japoneses que não hesitou em fazer um vasto uso de técnicas ocidentais de escrita, sem, ao mesmo tempo, deixar de se apoiar largamente nos padrões estéticos e literários tradicionais japoneses.

Shisei, conto objeto do presente estudo, pertence ao primeiro estágio da vida literária de Tanizaki. É nessa fase de sua carreira (1910-1928), que a influência de autores ocidentais, tais como Edgar Allan Poe, Charles Baudelaire, Oscar Wilde, Émile Zola e Thomas Hardy, é mais evidente em suas obras (MORRIS, 1962: 90; KAMEI, 1979: 149; LIPPIT, 1977: 224-225).

Morris (1962: 90) destaca que tal influência da literatura ocidental foi importante para canalizar o romantismo de Tanizaki rumo à sensualidade. Pode-se observar também nítida presença de Edgar Allan Poe na obsessão de Tanizaki por temas como crueldade e aberração sexual, bem como na ambientação de suas obras, cercada por uma aura de mistério, por vezes relacionada a forças ocultas ou demoníacas. Etô (1964: 436-437) destaca que essa defluência de ideias de autores ocidentais resultou em uma visão da beleza como perigosa, perversa e fatal nos contos de Tanizaki, ou seja, uma beleza que valeria a pena sacrificar-se para assegurar o seu alcance.

Vários autores e críticos Japoneses referem-se à Tanizaki na primeira fase de sua carreira literária como o escritor do satanismo (akumashugi 悪魔主義), uma vez que seus trabalhos envolvem temas avessos à moral e a valores sociais da época, incluindo, de um lado, o hedonismo e o erotismo, e de outro, o sadismo, o grotesco e o macabro (SEIDENSTICKER, 1966: 251; LIPPIT, 1977: 225). O crítico Kobayashi Hideo (apud SEIDENSTICKER, 1966: 254), por exemplo, afirmou que Tanizaki seria um idealista sensual (kannôteki risôka 官能的理想化) completamente fiel às tentações da vida e que necessita constantemente de excitação carnal.

Nagai Kafû (apud SEIDENSTICKER, 1966: 253), escritor japonês contemporâneo a Tanizaki que escrevia sobre o cotidiano de gueixas, prostitutas e profissionais de entretenimento nos bairros de Tóquio do início do século XX, ao refletir sobre as principais características de Tanizaki nesse estágio inicial, sustenta que o autor possuía uma qualidade misteriosa e mística (shinpi yûgen 神秘幽玄) resultante de um medo carnal (nikutaiteki kyôfu 肉体的恐怖), ou seja, um prazer intenso criado pela reação à mortificação da carne. Cumpre destacar que a palavra yûgen (幽玄) utilizada por Kafû refere-se a um valor estético tradicional japonês, relacionado a uma beleza sutil, misteriosa e escondida, que não é facilmente expressa por palavras, e deve ser inferida pelo contexto (SORTE JUNIOR, 2013: 11), enquanto que shinpi (神秘) traduz-se como misticismo. Em virtude dessa 
associação entre shinpi yûgen e nikutaiteki kyôfu, as obras de Tanizaki na primeira fase de sua vida literária são capazes de criar uma beleza misteriosa, oriunda de uma atmosfera de crueldade, sadismo e perversão, o que leva Kafû (apud SEIDENSTICKER, 1966: 253) a afirmar que as obras de Tanizaki nesse período carregam em si um conteúdo de dor e beleza análogo ao de uma cena de assassinato em uma peça do teatro Kabuki.

Suzuki (1996: 23) assevera que as críticas literárias acerca das obras de Tanizaki correspondentes ao primeiro estágio de sua carreira enfatizam o aspecto sádico e diabólico de seus contos porque tal estágio antecedeu o estilo ero guro nansensu (エ ログロナンセンス). Esse estilo é caracterizado pela cultura do erótico, grotesco e absurdo e se tornou extremamente popular no Japão no fim da década de 1920 e início da década de 1930. Conforme Suzuki (1996: 25):

\begin{abstract}
"Os textos publicados por Tanizaki durante o período Taishô [1912-1926] - obras que foram injustamente caracterizadas como anormais ou meramente excêntricas - combinam fantasia e erotismo com o chocante e grotesco, assim como com o absurdo e sem sentido, de uma forma que antecede de maneira marcante a cultura ero guro nonsense da segunda metade dos anos 1920s e início dos anos 1930s." ${ }^{2}$
\end{abstract}

Assim como Shisei, outros contos da primeira fase da vida literária de Tanizaki também versam sobre o sadomasoquismo, procurando associar o amor e a beleza à crueldade. É o caso da obra Amor Insensato (Chijin no ai 痴人の愛), na qual o casal retratado no livro consegue melhorar o seu relacionamento por meio de práticas sadomasoquistas:

“O 'amor' que eles expressam como uma união de mente e corpo inspira Jôji e Naomi a se aprimorarem por intermédio do casamento. Eles articulam o desejo de se tornarem um casal 'admirável,' que luta para se aperfeiçoar e agradar um ao outro. E, de fato, Jôji e Naomi se tornam inseparáveis como marido e esposa. A ironia é que o sucesso dessa união surge por meio do desenvolvimento de uma relação sadomasoquista. Tal 'melhora', logicamente, queda-se em completa oposição à ideologia convencional de casamento que enfatiza o aprimoramento moral, cultural e intelectual de cada um dos cônjuges" ${ }^{3}$

2 Livre tradução do autor. O texto original possui a seguinte redação: "The texts Tanizaki published during the Taishô period - texts that have been unjustly characterized as abnormal or merely eccentric - thus combine fantasy and eroticism with the lurid and grotesque, as well as with the absurd and the nonsensical, in a way that strikingly anticipates the ero guro nansensu culture of the late-twenties and the early-thirties" (SUZUKI, 1996: 25).

3 Livre tradução do autor. O texto original possui a seguinte redação: "The 'love' they express as a coming together of the mind and body inspires Jôji and Naomi to better themselves through marriage; they articulate the desire to become an 'admirable' couple who strive to improve and please each 
O conto Shisei narra a história de Seikichi, um jovem e talentoso tatuador que, ao mesmo tempo que desempenhava com destreza seu ofício e era reconhecido pela sua arte, possuía secretas tendências sádicas, sentindo prazer na proporção que conseguia infligir maior dor em seus clientes. Seikichi há muitos anos nutria um desejo oculto de encontrar uma mulher perfeita e nela tatuar aquilo que seria sua obra-prima. Ele acaba por localizar essa mulher ideal. Inicialmente, tal mulher ideal aos olhos do tatuador mostra-se tímida como uma menina e Seikichi apresenta-lhe pinturas excêntricas retratando mulheres poderosas perante homens que sucumbiram a seus pés. Apesar de tentar demonstrar aversão às pinturas, as atitudes da jovem parecem indicar certa semelhança entre sua personalidade e a das mulheres estampadas nas pinturas. Seikichi, então, utiliza-se de um sedativo para entorpecer a menina e nas costas dela cria a tatuagem de uma aranha gigante, que considera ser a obra-prima de sua vida. É relatado que a elaboração daquela tatuagem esgotou toda a sua energia vital. Ao despertar do sono, a menina demonstra ter se transformado, dizendo que havia abandonado completamente sua timidez de antes. Afirma, finalmente, que Seikichi foi sua primeira "vítima". É relevante destacar que, conforme será analisado mais a frente, o termo em japonês traduzido como “vítima” (肥料) sugere a ideia de que a heroína faz uso dos homens para atingir seus próprios desejos, levando-os à ruína como resultado.

A próxima seção descreverá com maior riqueza de detalhes o conto em destaque, apresentando alguns de seus trechos mais profundamente associados ao tema central deste artigo.

\section{O conto Shisei: a criação da beleza pelo sadismo}

O conto Shisei tem como ambientação os bairros de prazer de Edo por volta de 1840. No período Edo (1603-1868), vale ressaltar, a prática de tatuar-se era comum entre indivíduos de classes menos abastadas, sobretudo entre aqueles envolvidos em atividades de entretenimento em distritos do prazer. O conto, apesar de exaltar a tatuagem como prática capaz de embelezar os corpos dos citadinos da época, implicitamente admite que essa atividade não era vista em pé de igualdade com outras expressões artísticas da era Edo. É o que se infere da seguinte passagem:

other. And indeed, Jôji and Naomi do become inseparable as husband and wife; the irony is that the success of their union comes about through its development as a sadomasochistic relationship. Such an 'improvement,' of course, stands in stark opposition to the mainstream love marriage ideology that stresses the moral, cultural, and intellectual betterment of the couple's 'selves"' (SUZUKI, 2005: 371)". 
"Anteriormente, Seikichi ganhava a vida como pintor de gravuras Ukiyo-e, seguindo os estilos de Toyokuni e Kunisada ${ }^{4}$. Apesar de ter decaído ao nível de tatuador, ele ainda manteve seu espírito de artista com grande sensibilidade." ${ }^{{ }^{5}}$

É exatamente nesse ambiente representado pelos bairros do prazer de Edo que a prática da tatuagem mostra-se como uma arte apreciada pela sua capacidade de ampliar a beleza das pessoas. Entretanto, o conto ressalta que a prática de tatuar-se não se restringia a párias e a membros de classes sociais hierarquicamente inferiores. Isso parece estar implícito no seguinte excerto, no qual Tanizaki afirma que a tatuagem era observada nos corpos dos citadinos e, em casos excepcionais, até mesmo em pessoas da classe dos samurais:

"Os que mais comumente traziam tatuagens em seus corpos eram pessoas como apostadores de jogos de azar e bombeiros, mas até mesmo citadinos ${ }^{6}$ e, ainda que mais raramente, os samurais também enfeitavam seus corpos dessa maneira."”

Sabe-se que no período Edo foi instituído pelo governo Tokugawa um rigoroso sistema de classes, que impedia a ascensão ou mudança de classes. O sistema era composto por quatro classes, sendo que a dominante era a dos samurais, seguida sucessivamente pela dos camponeses, dos artesãos e, finalmente, dos comerciantes. Havia, ainda, grupos que estavam abaixo desse sistema de classes, incluindo profissionais do entretenimento como atores, bem como grupos situados acima de tal sistema, representados por monges budistas e xintoístas, o imperador e a família imperial, além dos xoguns da família Tokugawa. Os comerciantes, apesar de ocuparem a base e, por conseguinte, a menor posição hierárquica dentro da sociedade Edo, começaram a expandir o seu poder nesse período em função da ampliação de seu domínio econômico, acompanhada da gradativa

4 Kunisada foi um renomado discípulo do mestre Toyokuni, que também se tornou um grande artista de gravuras Ukiyo-e. Quando um discípulo estava apto a desenvolver suas próprias obras originais, era comum que seu mestre lhe escolhesse um nome artístico. O mestre, então, utilizava uma sílaba do seu próprio nome para criar o de seu discípulo. Por essa razão, Kunisada herdou a sílaba "kuni" de seu mestre Toyokuni (MARKS, 2010, p. 12).

5 Livre tradução do autor. O texto original possui a seguinte redação: もと豊国国貞の風を慕って、 浮世絵師の渡世をしていただけに、刺青師に阼落してからの清吉にもさすが画工らしい良 心と、鋭感とが残っていた (TANIZAKI, 1966).

6 O termo aqui traduzido como “citadinos" é chônin (町人). Cumpre destacar que apesar de se tratar de sua tradução literal, no período Edo esse termo era utilizado para designar, de forma mais específica, comerciantes e artesãos, uma vez que eles compunham parcela majoritária da população urbana (KOMATSU, 2016: 12).

7 Livre tradução do autor. O texto original possui a seguinte redação: 博徒、鳶の者はもとより、町人 から稀には侍なども入墨をした (TANIZAKI, 1966). 
decadência financeira dos samurais (SORTE JUNIOR, 2016: 326-327, 337). O conto retrata como as tatuagens, e por conseguinte a profissão do tatuador, eram encaradas de forma ambígua pela sociedade, pois apesar de existir preconceito por ser uma atividade vista como degenerada, até mesmo segmentos altos da sociedade já aceitavam como expressão válida de beleza.

$\mathrm{Na}$ verdade, essa ambiguidade pode ser encarada como fruto de um traço marcante da sociedade Edo: a coexistência harmônica de diferentes expressões artísticas outrora consideradas incompatíveis. Foi nessa época que se observou processo gradativo de fusão entre dois tipos literários até então antagônicos: (i) $g a$ (雅), ou seja, a considerada literatura elegante, que incluía prosa e poesia em chinês clássico, poesia da corte japonesa, clássicos literários japoneses no formato monogatari (物語) etc.; e (ii) zoku (俗), isto é, gêneros considerados vulgares como o ukiyo zôshi (浮世草子), poemas estilo haiku (俳 句) etc. (SORTE JUNIOR, 2016: 331). Com a interação crescente das diferentes classes no meio urbano ocorrido no período Edo, observa-se que essa segmentação estética, não só no campo literário mas também em outras expressões artísticas, começa a ceder lugar para um maior sincretismo. O conto Shisei ilustra essa aceitação, incorporação e até mesmo união de diferentes expressões artísticas pela sociedade Edo.

Acredita-se que o Japão foi uma das primeiras localidades no mundo em que as pessoas faziam grandes tatuagens, cobrindo partes consideráveis de seus corpos, enquanto que em outros países as tatuagens se restringiam a pequenas marcas em locais isolados. É certo que na história do Japão, a tatuagem já foi utilizada como punição a criminosos imposta pelo estado. Muitas pessoas também se tatuavam como forma de insurgência à autoridade e, a partir do período Edo, tal prática em certos momentos foi inclusive proibida por decretos governamentais (GAMBORG, 2012: 25, 31, 40). Não obstante, o conto de Tanizaki tende a se distanciar tanto dessas conotações históricas da tatuagem, quanto dos problemas sociais urbanos do período Edo. Na verdade, o parágrafo inicial de Shisei, abaixo transcrito, parece descrever uma ambientação idealizada para o conto, uma visão de Edo voltada para o enfoque fantasioso do "mundo flutuante" (ukiyo 浮世):

\begin{abstract}
"Era uma época em que as pessoas possuíam a admirável virtude da 'frivolidade', quando a vida não era tão marcada por uma luta incessante como se vê atualmente. Era um período no qual se levava uma vida calma e agradável, em que os jovens lordes e aristocratas exibiam um rosto calmo, sem traços de tensão, as damas da corte e gueixas mantinham um sorriso que nunca se esgotava, a atividade dos vendedores de chá e profissionais do entretenimento era tida como elegante." ${ }^{8}$
\end{abstract}

8 Livre tradução do autor. O texto original possui a seguinte redação: それはまだ人々が「愚」と云 う貴い徳を持っていて、世の中が今のように激しく軋み合わない時分であった。殿様や若 旦那の長閑な顔が曇らぬように、御殿女中や華魁の笑い種が尽きぬようにと、饒舌を売る お茶坊主だの幇間だのと云う職業が、立派に存在して行けたほど、世間がのんびりしてい た時分であった (TANIZAKI, 1966). 
Os caracteres japoneses utilizados para a escrita da palavra ukiyo (浮世) em referência ao estilo estético originado no período Edo são traduzidos como "mundo flutuante". Trata-se de um trocadilho com um termo homófono grafado com caracteres diferentes (憂き世), que é amplamente utilizado na filosofia budista e se encontra associado à ideia de sofrimento e infortúnio, de modo a expressar o caráter efêmero e impermanente da vida. A partir do período Edo, o termo ukiyo gradualmente perde a conotação filosófica do budismo e passa a ser mais amplamente utilizado para significar o "mundo flutuante", referindo-se à procura de uma vida repleta de entretenimento, na qual todos devem se esforçar para aproveitar a experiência mundana ao máximo, na busca incessante pelo prazer (SORTE JUNIOR, 2016: 330).

Dessa forma, mesmo versando sobre uma tatuagem, o conto não se refere às utilizações negativas relacionadas a essa prática em determinados momentos históricos no Japão. Apesar de constituir uma prática mais amplamente usada por classes menos abastadas da sociedade Edo, Tanizaki não se restringe a ressaltar o caráter exclusivamente depreciativo dessa expressão artística. Ao contrário, tenta associá-la com o "mundo flutuante", marcado por uma vida pacata, feliz e prazerosa levada pelos citadinos de Edo, da qual todas as classes sociais participavam. De certo, trata-se de um retrato idealizado do período Edo, mas que remete o leitor a um mundo fantasioso, lúdico e belo. Isso se coaduna com o estilo de Tanizaki nas obras da primeira fase de sua vida literária, nas quais o autor parece tentar demonstrar que a beleza e a sensualidade podem emanar daquilo que a princípio se mostra sádico, cruel e até grotesco. A utilização da tatuagem permite mostrar a participação do sadismo e da crueldade na construção da sensualidade e na busca da beleza ideal, acrescentando um caráter tenebroso ou perverso na procura do belo, um tema que vários autores, tais como Seidensticker (1966: 251), Suzuki (1996: 23) e Lippit (1977: 229), associam às obras da primeira fase da vida literária de Tanizaki. A opção pela tatuagem no conto pode também ser encarada como uma forma vislumbrada por Tanizaki de representar a atuação do artista sobre o canvas - nesse caso, o próprio corpo da menina - para a criação de sua obra-prima.

A escolha de um tatuador como protagonista e do período Edo para a ambientação do conto, época em que surgiu a concepção do ukiyo e também se difundiu a prática da tatuagem, tende a demonstrar que o intuito principal de Tanizaki era criar um mundo ideal no qual poderia desenvolver a história de um artista em busca da beleza absoluta e da associação do belo e do erótico ao tenebroso e sádico.

Lippit (1977: 229-230) afirma que nas obras de Tanizaki os temas da descoberta do caráter perverso na natureza humana e o desejo masoquista da autodestruição estão intrinsecamente correlacionados e encontram-se também associados à busca da femme fatale. Segundo o autor, isso pode ser confirmado em Shisei, no qual o prazer sádico que sentia o tatuador protagonista Seikichi, ao observar a dor extrema e agonia de seus clientes enquanto eram tatuados, acaba por se transformar em um desejo masoquista de tornar-se vítima de uma mulher dotada de um ideal absoluto de beleza. 
O conto carece de elementos que comprovem veementemente tal caráter masoquista de Seikichi. É certo que, ao fim do conto, Seikichi confessa ter esgotado todo o seu potencial artístico na criação de sua "obra-prima" e acaba se tornando a primeira "vítima" da sua criação. Não obstante, não há elementos no texto que comprovem um desejo masoquista explícito, ou mesmo latente, de Seikichi em ser vitimado por sua criação. Tal desejo masoquista pode ser apenas inferido pela interpretação do leitor. $\mathrm{O}$ que se mostra claro e evidente pela leitura textual são as tendências sádicas de Seikichi, que podem ser comprovadas já no início do conto, na forma como sentia prazer ao observar a agonia e dor de seus clientes. É o que se depreende da seguinte passagem:

\begin{abstract}
"No interior do coração desse jovem tatuador, escondiam-se prazeres e desejos secretos. No momento em que introduzia sua agulha na pele de seus clientes, a maioria soltava gemidos de agonia ao sentir a dor insuportável daquela perfuração na pele inchada embebida de sangue encarnado. À medida que esses gemidos se mostravam mais intensos, estranhamente também se tornava mais forte o prazer sentido pelo tatuador."
\end{abstract}

Lippit (1977: 230) destaca que os protagonistas das obras de Tanizaki dedicam-se de forma extrema ao alcance da essência absoluta da beleza feminina. Essa dedicação é clara em Shisei, pois há uma busca obstinada do tatuador Seikichi pela mulher perfeita, que será utilizada como um verdadeiro canvas para realizar a sua obra-prima. Já no início desse conto, Tanizaki ressalta a importância ímpar que atribui ao belo e a relação intrínseca entre a beleza e o poder:

“(...) seja no teatro ou na literatura daquela época, todas as coisas belas eram sinônimas de poder, enquanto que as coisas feias eram sinônimas de fraqueza." ${ }^{10}$

Quase ao fim do conto, quando a heroína está em processo de despertar sua personalidade latente a fim de alcançar a qualidade suprema de beleza aos olhos do tatuador Seikichi, uma frase por ela proferida também demonstra o papel central do belo para os personagens do conto:

9 Livre tradução do autor. O texto original possui a seguinte redação: この若い刺青師の心には、人 知らぬ快楽と宿願とが潜んでいた。彼が人々の肌を針で突き刺す時、真紅に血を含んで脹 れ上がる肉の疼きに堪えかねて、大抵の男は苦しき呻き声を発したが、その呻きごえが激 しければ激しいほど、彼は不思議に云い難き愉快を感じるのであった (TANIZAKI, 1966).

10 Livre tradução do autor. O texto original possui a seguinte redação: ... 当時の芝居でも草雙紙でも、 すべて美しい者は強者であり、醜い者は弱者であった (TANIZAKI, 1966). 
"Eu posso suportar qualquer coisa para me tornar bela." "11

Morris (1962: 91) frisa a veneração sensual ou sensorial da mulher presente nas obras de Tanizaki, um tipo raro de adoração na literatura japonesa. Segundo o autor:

“A menina do conto 'A Tatuagem' é uma heroína típica das obras iniciais de Tanizaki: ela possui uma beleza sensual peculiar que, combinada ao seu sadismo latente, é capaz de despertar uma forma pervertida de excitamento no artista-observador." 12

Esse sadismo latente fica aparente no comportamento da heroína do conto quando Seikichi lhe mostra uma pintura que retrata a imperatriz Chou, esposa do déspota chinês Chu da dinastia Shang, observando um homem condenado à morte e prestes a ser sacrificado. A imperatriz é uma personagem real, historicamente famosa pela sua crueldade, e, na pintura apresentada por Seikichi, encontra-se vestida de forma elegante e defronte ao condenado. Tanizaki descreve que, ao observar essa pintura, a heroína começa a alterar a sua expressão, adquirindo inconscientemente um brilho nos olhos e um tremor nos lábios, e paulatinamente se assemelha à expressão da imperatriz retratada na pintura:

"Por algum tempo a menina observou aquela pintura estranha. Sem saber e sem perceber seus olhos começaram a brilhar e seus lábios a tremer. Curiosamente, seu rosto começou a se assemelhar gradualmente à face da imperatriz. Naquela pintura, a menina se deparava com o seu verdadeiro eu secreto."13

Seikichi destaca esse sadismo latente da heroína ao compará-la diretamente à imperatriz retratada na pintura, com as seguintes frases: "Esta pintura reflete a sua verdadeira essência" e "A mulher nesta pintura é você. O sangue desta mulher certamente corre pelo seu corpo" 14 .

11 Livre tradução do autor. O texto original possui a seguinte redação: 「美しくさえなるのなら、どん なにでも辛抱して見せましょうよ」

12 Livre tradução do autor. O texto original possui a seguinte redação: "The girl in 'Tattoo' is typical of Tanizaki's early heroines: she possesses a peculiar sensous beauty which, combined with her latent sadism, is capable of arousing a perverted form of excitement in the artist-observer" (MORRIS, 1962: 91).

13 Livre tradução do autor. O texto original possui a seguinte redação: 娘は暫くこの奇怪な絵の面を 見入っていたが、知らず識らずその瞳は輝きその唇は顫えた。怪しくもその顔はだんだん と妃の顔に似通って来た。娘は其処に隠れたる真の「己」を見出した (TANIZAKI, 1966).

14 Livre tradução do autor. O texto original possui a seguinte redação:「この絵にはお前の心が映 っているぞ」 e 「この絵の女はお前なのだ。この女の血がお前の体に交っている筈だ」

(TANIZAKI, 1966). 
Ao mesmo tempo que seus olhos brilham e sua expressão facial se assemelha ao rosto da imperatriz, entretanto, a heroína verbaliza uma reação de aversão à pintura, dizendo: "Por que você está me mostrando algo tão horrível?"”5. Essa disparidade entre as suas expressões física e oral tende a demonstrar que a menina de fato possuía, de forma latente, a personalidade que Seikichi lhe atribuía, embora tivesse medo de aceitar esse seu traço e parecia sentir-se horrorizada com os sentimentos que o tatuador fazia despertar.

Seikichi apresenta à heroína uma segunda pintura que retrata uma mulher apoiada em uma árvore de cerejeira tendo, aos seus pés, inúmeros corpos de homens. Percebe-se um traço de orgulho, vaidade e satisfação no rosto da mulher da pintura. Seikichi mais uma vez associa a imagem à personalidade e ao futuro da heroína ao lhe proferir as seguintes palavras:

"Este é o seu futuro estampado na pintura. As pessoas que aqui sucumbiram são todos que a partir de agora vão dar suas vidas por você."”

Mais uma vez, a heroína externaliza uma reação de aversão à pintura apresentada por Seikichi, afirmando: "Eu lhe peço encarecidamente, por favor guarde logo essa pintura." ${ }^{17}$ Suas atitudes mostram-se novamente contrárias a sua expressão oral, pois apesar de tentar esconder seu rosto mostrando não querer ver a imagem, volta a apresentar tremor nos lábios, donde se infere certo interesse pela pintura e pelos sentimentos que Seikichi procurava instigar. Esse sentimento ambíguo de repugnância e atração também pode ser deduzido da seguinte frase proferida pela menina:

"Confesso que realmente possuo natureza semelhante à da mulher da pintura como você diz. Então, por favor tenha pena de mim e guarde essa pintura."18

É certo que essa confissão por parte da menina pode ser interpretada tanto como uma aceitação de que realmente possuía a personalidade das mulheres retratadas nas pinturas, quanto como uma tentativa desesperada de fazer com que Seikichi parasse de estimular

15 Livre tradução do autor. O texto original possui a seguinte redação:「どうしてこんな恐ろしいもの を、私にお見せなさるのです」(TANIZAKI, 1966).

16 Livre tradução do autor. O texto original possui a seguinte redação:「これはお前の未来を絵に現し たのだ。ここに斃れている人達は、皆これからお前の為めに命を捨てるのだ」 (TANIZAKI, 1966).

17 Livre tradução do autor. O texto original possui a seguinte redação:「後生だから、早くその絵を しまって下さい」(TANIZAKI, 1966).

18 Livre tradução do autor. O texto original possui a seguinte redação:「親方、白状します。私はお 前さんのお察し通り、その絵の女のような性分を持っていますのさ。一だからもう堪忍し て、それを引っ込めておくんなさい」(TANIZAKI, 1966). 
aqueles sentimentos. Não obstante, essa confissão e as demais reações da menina evidenciam que estava sendo tocada, de alguma forma, pelas atitudes e frases de Seikichi.

A procura por uma mulher ideal, expressão da beleza absoluta, é o objetivo expresso de Seikichi desde o início do conto. A seguinte passagem demonstra essa longa e incessante procura de Seikichi por uma mulher cuja beleza transcendesse a aparência física e incorporasse também traços de personalidade ideais, a fím de preencher todos os requisitos de beleza suprema segundo a concepção do tatuador:

\begin{abstract}
"Por muitos anos, Seikichi nutria uma ambição de encontrar uma bela mulher com uma pele resplandecente, e nela esculpir a essência de sua alma de artista. Essa mulher deveria atender a uma série de qualidades de personalidade e aparência. Apenas um lindo rosto ou uma bela pele não eram suficientes para atender aos seus padrões. Apesar de ter procurado dentre as mais famosas cortesãs dos bairros de prazer de Edo, ainda não tinha encontrado aquela que se encaixasse em seu ideal. Três ou quatro anos se passaram, Seikichi mantinha em sua mente a imagem ideal da mulher que procurava, mas mesmo não a encontrando, não perdia as esperanças." 19
\end{abstract}

Fica implícito no conto que a beleza absoluta da mulher procurada por Seikichi seria alcançada pela ação do próprio tatuador. Apesar de procurar uma mulher que preenchesse seus requisitos quanto à beleza física e ao perfil psicológico, essa mulher atingiria a beleza absoluta pela ação artística do tatuador sobre a sua pele. Por essa razão, Lippit (1977: 230) afirma ser o principal tema de Shisei a criação por Seikichi de uma mulher fatal com a finalidade de ser por ela torturado. Conforme já discutido, não há registro explícito textual que demonstre a existência de um desejo masoquista por parte de Seikichi de ser destruído pela sua criação. Entretanto, é certo que Seikichi dedica-se completamente à criação da tatuagem nas costas da menina e, ao fim do conto, Tanizaki expressamente afirma que o tatuador se sentiu vazio, ao transferir àquela obra-prima toda a sua alma (tamashii 魂) e potencial:

"Aquela tatuagem em si era tudo na vida de Seikichi. Ao terminar o trabalho, sentiu que seu interior estava completamente vazio." ${ }^{20}$

19 Livre tradução do autor. O texto original possui a seguinte redação: 彼の年来の宿願は、光輝ある 美女の肌を得て、それへ己れの魂を刺り込む事であった。その女の素質と容貌とに就いて は、いろいろの注文があった。旁に美しい顔、美しい肌とのみでは、彼は中々満足する事 が出来なかった。江戸中の色町に名を響かせた女という女を調べても、彼の気分に適った 味わいと調子とは容易に見つからなかった。まだ見め人の姿かたちを心に描いて、三年四 年は空しく憧れながらも、彼 はなおその願いを捨てずにいた (TANIZAKI, 1966).

20 Livre tradução do autor. O texto original possui a seguinte redação: その刺青こそは彼が生命のすべ てであった。その仕事をなし終えた後の彼の心は空虚であった (TANIZAKI, 1966). 
O tatuador também afirma expressamente que colocou o seu potencial total na tatuagem, de modo a transformar a menina em uma beleza absoluta, sem rival em todo o Japão:

\begin{abstract}
"Para lhe transformar em uma mulher verdadeiramente bonita, eu despejei minha própria alma nessa tatuagem. Já não há em todo Japão mulher capaz de se tornar sua rival. Você não precisa mais manter a postura tímida que outrora possuía. Todos os homens se tornarão suas vítimas. ${ }^{21}$
\end{abstract}

Depois de concluir a tatuagem nas costas da menina, é interessante também reparar que Tanizaki deixa de se referir à heroína com o termo "menina" (musume 娘) e passa a usar a palavra "mulher" (onna 女). Por ter utilizado completamente o seu potencial para nutrir o crescimento da menina e transformá-la em uma mulher semelhante àquelas representadas nas pinturas, ao fim do conto a heroína afirma que o tatuador foi a sua primeira “vítima” (肥料):

"Já me desfiz completamente da postura tímida que tinha até então. E você se tornou a minha primeira vítima"22.

É importante aqui realizar uma breve digressão sobre o termo hiryô (肥料) utilizado na frase acima e também como nome da segunda pintura apresentada por Seikichi à heroína. A tradução literal do termo significa fertilizante ou adubo, mas a palavra é utilizada metaforicamente no conto. Segundo Tobias (2009: 50) o primeiro ideograma é oriundo do verbo koeru (肥える), que significa “engordar", enquanto o segundo, ryô (料), traz a ideia de material. Assim, o termo refere-se ao fato de que, tanto a heroína do conto quanto a mulher da pintura, utilizavam-se dos homens para se nutrir (tornarem-se mais poderosas ou ricas) e depois destruí-los. Essa interpretação encontrase em harmonia com a simbologia da aranha, tratada mais adiante na presente discussão, tatuada nas costas da menina.

Lippit (1977: 131) destaca também que Seikichi, por meio da sua intervenção artística sobre a pele da heroína, tatuando uma enorme aranha, transforma uma menina inocente em uma mulher cruel, sendo que, nesse caso, a arte funcionaria como um

21 Livre tradução do autor. O texto original possui a seguinte redação:「己はお前を本当の美しい女 にする為めに、刺青の中へ己の魂をうち込んだのだ。もう今からは日本国中に、お前に優 る女は居ない。お前はもう今までのような臆病な心は持っていないのだ。男と云う男は、 皆なお前の肥料になるのだ。….... (TANIZAKI, 1966).

22 Livre tradução do autor. O texto original possui a seguinte redação: 「親方、私はもう今までのよ うな臆病な心を、さらりと捨ててしまいました。一一お前さんは真先に私の肥料になった んだ政え」(TANIZAKI, 1966). 
agente para a criação do mal. Não obstante, parece mais sensato afirmar que a atuação de Seikichi apenas fez despertar traços já presentes de forma latente na menina, intensificando a sua beleza e esculpindo a sua personalidade de forma a alcançar o ideal de beleza absoluta para Seikichi. Na verdade, o comportamento dual da menina descrito acima, consubstanciado no sentimento ambíguo de horror e atração pelas pinturas apresentadas por Seikichi, tende a refletir tais características sádicas latentes.

Tobias (2009: 46) explora algumas simbologias utilizadas por Tanizaki em Shisei, demonstrando que o conto trata de temas como o amor obsessivo, as forças destrutivas da sexualidade e a natureza dual feminina de deusa e demônio. É interessante apresentar a discussão do autor no que diz respeito ao tipo de aranha, nephila clavata (Jorôgumo 女郎蜘蛛), tatuada por Seikichi nas costas da menina:

“A aranha Jorô é associada à beleza, mas também ao veneno. Além disso, [jorôgumo] 女郎蜘蛛 é também o nome usado para um ser mitológico do folclore japonês. Por vezes é representado por uma criatura metade mulher, metade aranha, já outras como uma aranha que se transforma em uma linda mulher para atrair suas presas. É dito que essa criatura aprisiona humanos em sua teia e os devora, ou exala uma fumaça azul que consome sua força vital. Essa metáfora da 'mulher venenosa' constitui uma antiga simbologia na literatura japonesa (...) e sua importância neste conto é rapidamente identificada. Torna-se evidente pelas suas reações às pinturas que a menina secretamente anseia por se tornar uma [jorôgumo] 女郎蜘蛛, de modo a atrair homens e conquista-los com sua beleza, destruindo-os em benefício próprio. Ela é muito tímida para perceber seus desejos até que a aranha é tatuada em suas costas, a transformando e a empoderando a fim de que se torne forte, bela e fatal. ${ }^{23}$

O caráter sensual da obra de Tanizaki pode ser exemplificado pela descrição minuciosa do pé da menina, que é visto por Seikichi ainda antes do encontro entre os dois. Tanizaki enfatiza a perfeição do pé, caracterizado pela sua forma e brancura, traço tradicionalmente valorizado pela estética japonesa (WAGATSUMA, 1967). Apesar de alguns autores ressaltarem o fetiche de Tanizaki por pés (SUZUKI, 1996: 24), frisa-se

23 Livre tradução do autor. O texto original possui a seguinte redação: “The 'courtesan spider' is associated with beauty, but also with poison. Moreover, 女郎蜘蛛 is also the name used for a mythical creature found in Japanese folk tales. It is sometimes depicted as a half-woman, half-spider, or otherwise as a spider that transforms itself into a beautiful woman in order to lure its prey. This creature is said to entangle humans in its thread and devour them, or breathe a blue smoke that sucks out their lifeblood. This metaphor of the 'poisonous woman' is a longstanding symbol in Japanese literature (...) and its importance in this story is readily apparent. It becomes evident from her responses to the paintings that the girl secretly aspires to be like the 女郎蜘蛛, to lure men and conquer them with her beauty, destroying them for her own sake. She is too timid to realize her desires until the spider is tattooed on her back, transforming her and empowering her so that she becomes strong, beautiful and deadly" (TOBIAS, 2009: 46). 
que essa passagem do texto também se caracteriza por um recurso literário denominado pars pro toto, ou seja, a identificação de um objeto em sua integralidade em função da associação com uma pequena parte dele (EISENSTEIN, 1957: 133). Na verdade, Tanizaki retoma em várias partes do conto a imagem do pé da menina que, portanto, não se refere apenas a uma parte do corpo, mas funciona como uma alusão à beleza da personagem por inteiro. Em outras palavras, a descrição minuciosa e poética da beleza desse pé no início do conto remonta a própria beleza da personagem e a referência a esse pé em partes posteriores de Shisei relembra o leitor da beleza sublime da personagem.

Ao mesmo tempo que descreve a beleza e perfeição do pé da menina, entretanto, vale lembrar que Tanizaki não deixa de apresentar certo toque de sadismo ou crueldade ao afirmar que aquele pé tinha as qualidades necessárias para subjugar e pisotear os homens. A escolha de descrever e ressaltar a beleza do pé da menina, portanto, justificase também pela relação dessa parte do corpo com as ações de pisar, pisotear, dominar ou submeter outrem. Pode-se depreender essa dupla característica da descrição do pé da menina - de beleza e dominação - da seguinte passagem do texto:

"Em uma noite de verão durante o quarto ano da busca de Seikichi [pela mulher perfeita para sua obra-prima], quando estava passando em frente ao restaurante Hirasei no bairro Fukagawa, ele percebeu o pé níveo descalço de uma mulher saindo da sombra da cortina de um palanquim parado no portão de entrada. Para seus olhos perspicazes, um pé humano era tão expressivo quanto o próprio rosto de uma pessoa. Para ele, o pé dessa mulher era uma pedra preciosa em forma de magnífica matéria carnal. Todos os cinco dedos possuíam um arranjo delicado, unhas da cor iridescente das conchas do litoral da ilha Enoshima, calcanhar oval como uma pérola e pele tão límpida que parecia ter sido banhada nas águas da fonte de uma montanha. De fato, aquele era um pé que deveria ser nutrido pelo sangue de homens e pisar em seus corpos. Seikichi sabia que a mulher possuidora daquele pé era quem ele vinha incessantemente buscando por todos esses anos." ${ }^{24}$

Além de diversas associações metafóricas relevantes apontadas por Tobias (2009: 48-49), como a referência a uma pérola ao tratar do formato arredondado do calcanhar, ou a comparação de um pé a uma pedra preciosa de valor e beleza tão raros que Seikichi deveria tentar conseguir a qualquer custo, destaca-se também no trecho acima transcrito

24 Livre tradução do autor. O texto original possui a seguinte redação: ちょうど四年目の夏のとある

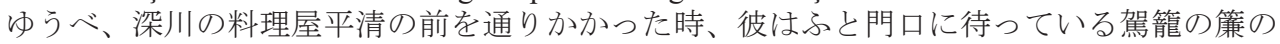
かげから、真っ白な女の素足のこぼれているのに気がついた。鋭い彼の眼には、人間の足 はその顔と同じように複雑な表情を持って映った。その女の足は、彼に取っては貴き肉の 宝玉であった。拇指から起って小指に終わる繊細な五本の指の整い方、絵の島の海辺で獲 れるうすべに色の貝にも劣らぬ爪の色合い、珠のような踵のまる味、清洌な岩間の水が絶 えず足下を洗うかと疑われる皮膚の潤沢。この足こそは、やがて男の生血に肥え太り、男 のむくろを踏みつける足であった。この足を持つ女こそは、彼が永年たずねあぐんだ、女 の中の女であろうと思われた (TANIZAKI, 1966). 
a ênfase na crueldade ou sadismo, quando o autor afirma que aquele pé seria digno de se nutrir de homens e pisar em seus corpos.

Por fim, cumpre salientar que a ênfase de Tanizaki na associação entre sensualidade e sadismo, visando ao alcance da beleza absoluta, não parece ser um traço resultante unicamente da influência da estética ocidental no início de sua carreira. Em sua obra Elogio às sombras (In'ei Raisan 陰笌礼讃), Tanizaki (1977: 18) afirma que a estética japonesa valoriza a beleza não do objeto em si, mas do contraste entre luz e escuridão que resulta em variados tipos de sombras que os objetos criam em outros. O autor também ressalta que o conceito de beleza criado pelos seres humanos provém da realidade em que vivem. Assim, como os japoneses tradicionalmente residiam em casas nas quais prevalecia ambientes escuros, eles aprenderam a retirar ou explorar a beleza das sombras (CHAMBERS, 1972: 39). Essa busca pela beleza em aspectos da vida não claramente ou diretamente relacionados com o belo, tais como as sombras ou a escuridão, pode ser retirada do conto Shisei, em que o sadismo, o tenebroso e o perverso configuram-se como elementos cruciais e imprescindíveis no processo do alcance da beleza absoluta.

\section{Conclusão}

O presente artigo centrou-se na análise do conto Shisei, no intuito de demonstrar como Tanizaki utilizou elementos relacionados ao sadismo, à crueldade e à perversão na construção da beleza e sensualidade. No conto, a criação da heroína sensual e sinônima do máximo padrão de beleza foi resultado não só da destreza do tatuador em inculcar sua obra-prima nas costas da menina, mas também das atitudes e frases perversas de Seikichi, que fizeram despertar na jovem desejos secretos e latentes de sadismo e crueldade.

Por fim, cumpre enfatizar que Shisei também se destaca pelo poder das metáforas que causam um poderoso efeito imagético no leitor. Tobias (2009) assevera que a riqueza de detalhes nesse conto dificulta a sua tradução e resultou em uma série de diferentes versões na língua inglesa. Essa riqueza de metáforas pode ser observada, por exemplo, na descrição do pé da menina acima transcrito, bem como na seguinte passagem:

"A alma do jovem tatuador se dissolveu na tintura e dispersou-se na pele da jovem. Cada gota de cinábrio que misturava ao álcool era como uma gota de sua força vital. Ali ele avistava a cor de sua própria alma."${ }^{25}$

Nessa passagem, Tanizaki parece fundir os instrumentos de trabalho utilizados por Seikichi para a criação da tatuagem com elementos do próprio corpo e espírito

25 Livre tradução do autor. O texto original possui a seguinte redação: 若い刺青師の霊は墨汁の中に 溶けて、皮膚に渗しだ。焼酎に交ぜて刺り込む琉球朱の一滴々々は、彼の命のしたたりで あった。彼は其処に我が魂の色を見た (TANIZAKI, 1966). 
do tatuador, de modo a mostrar que o protagonista dedicou-se plena e inteiramente à realização de sua obra-prima nas costas da menina.

Dessa forma, observa-se que o conto em apreço possui vários aspectos ainda inexplorados, razão pela qual futuros artigos que se dediquem à realização de novas traduções do conto para a língua portuguesa e a análises de aspectos linguísticos seriam de grande relevância para a teoria literária.

\section{Referências Bibliográficas}

CHAMBERS, Anthony. Tanizaki Junichirô's Historical Fiction. The Journal of the Association of Teachers of Japanese, Broadway, v. 8, n. 1, p. 34-44, 1972.

CONNELLY, Frances S. Introduction, in: CONNELLY, Frances S. (ed) Modern Art and The Grotesque. Cambridge: Cambridge University Press, p. 1-19, 2003.

DECCAN CHRONICLE. Violence is Beautiful: Kim Ki-Duk'. Deccan Chronicle, publicado em 12 de dezembro de 2013, disponível em: http://www.deccanchronicle.com/131212/ entertainment-mollywood/article/violence-beautiful-kim-ki-duk (acesso em 15 de março de 2017).

DODD, Stephen. History in the Making: The Negotiation of History and Fiction in Tanizaki Jun'ichirô's "Shunkinshô". Japan Review, Quioto, n. 24, p. 151-168, 2012.

EISENSTEIN, Sergei. Film Form - Essays in Film Theory. Nova York: Meridian Books, 1957.

ETÔ, Jun. An Undercurrent in Modern Japanese Literature. The Journal of Asian Studies, Cambridge, v. 23, n. 3, p. 433-445, 1964.

GAMBORG, Dag Joakim. Japanese traditional tattooing in modern Japan. Tese de Mestrado, Oslo, Faculdade de Humanidades, Universidade de Oslo, 2012.

GOLLEY, Gregory. Tanizaki Junichiro: The Art of Subversion and the Subversion of Art. Journal of Japanese Studies, Seattle v. 21, n. 2, p. 365-404, 1995.

HIBBETT, Howard. Tradition and Trauma in the Contemporary Japanese Novel. Daedalus, Cambridge, v. 95, n. 4, p. 925-940, 1966.

KAMEI, Shunsuke. Japanese Reception of American Literature until World War II. Comparative Literature Studies, Pensilvânia, v. 13, n. 2, p. 143-159, 1976.

KOMATSU, Teruyuki. "Reconsidering the Issue of Cultural, Ethnic, and Religious Identities": Learning from the History of Global Migration, Japanese History of Immigration, and a History of Cultural and Ethnic Identity. Journal of Nagoya Gakuin University, v. 52, n. 4, p. 1-21, 2016.

LIPPIT, Noriko Mizuta. Tanizaki and Poe: The Grotesque and the Quest for Supernal Beauty. Comparative Literature, Carolina do Norte, v. 29, n. 3, p. 221-240, 1977.

MARKS, Andreas. Japanese Woodblock Prints: Artists, Publishers and Masterworks: 1680-1900. Cingapura: Tuttle Publishing, 2010. 
MORRIS, Ivan. Tattoo by Tanizaki Jun'ichirô: translated by Ivan Morris, in: MORRIS, Ivan (org.). Modern Japanese Stories: An Athology. Cingapura: Tuttle Publishing, p. 90-91, 1962.

SEIDENSTICKER, Edward. Tanizaki Jun-ichirô, 1886-1965. Monumenta Nipponica, Tóquio, v. 21, n. 3/4, p. 249-265, 1966.

SORTE JUNIOR, Waldemiro Francisco. Bounded Rationality in the Japanese Cinema: Director Miwa Nishikawa's Yureru Revisits the "Rashômon Effect". Studies on Asia: An Interdisciplinary Journal of Asian Studies, Illinois, série IV, v. 3, n. 2, p. 1-30, 2013.

. Shifting Values Toward Profit-Making in Edo Japan: Insights from the Book Ugetsu Monogatari. Interdisciplinary Literary Studies, Pensilvânia, v. 18, n. 3, p. 325 342, 2016.

SUZUKI, Michiko. Progress and Love Marriage: Rereading Tanizaki Jun'ichirô's “Chijin no ai”. Journal of Japanese Studies, Seattle, v. 31, n. 2, p. 357-384, 2005.

SUZUKI, Sadami. Tanizaki Jun'ichirô as Cultural Critic. Japan Review, Quioto, n. 7, p. 23-32, 1996.

TANIZAKI, Jun'ichirô. Tattoo, in: Morris, Ivan (org.). Modern Japanese Stories: An Athology. Cingapura: Tuttle Publishing, p. 92-100, 1962.

. Shisei, in Nihonbungaku zenshû (dai12) Tanizaki Jun'ichirôshû (Coleção de obras completas da Literatura Japonesa número 12 - Tanizaki Jun’ichirô). Tóquio, Kawade Shobo Shinsha Publishers inc., p. 7-13, 1966.

In Praise of Shadows. Tradução para o inglês de Thomas J. Harper e Edward G. Seidensticker. Connecticut: Leete’s Island Books, 1977.

TOBIAS, Shani. Untangling and Re-spinning the Web: Translations of Metaphor in Tanizaki's "Shisei". The International Journal of Translation and Interpreting Research, Sidney, v. 1, n. 1, p. 44-54, 2009.

TSURUTA, Kinya. Tanizaki Jun'ichirô's Pilgrimage and Return. Comparative Literature Studies, Pensilvânia, v. 37, n. 2, p. 239-255, 2000.

WAGATSUMA, Hiroshi. The Social Perception of Skin Color in Japan. Daedalus, Cambridge, v. 96, n. 2, p. 407-443, 1967. 